\title{
Pemberian Terapi Oksigen Hiperbarik Tidak Memberikan Pengaruh Positif pada Ketebalan Endometrium pada Tikus Model Sindrom Ovari Polikistik dengan Resistensi Insulin
}

\author{
Lunardhi Susanto, ${ }^{1}$ Azham Purwandono, ${ }^{2}$ Ivon Diah Wittiarika, ${ }^{3}$ Budi Santoso ${ }^{4}$ \\ ${ }^{1}$ Bagian Biologi Seluler, Fakultas Kedokteran Universitas Hang Tuah Surabaya, Indonesia \\ ${ }^{2}$ Bagian Patologi Anatomi, Fakultas Kedokteran Universitas Jember, Indonesia ${ }^{3}$ Prodi Kebidanan, \\ Fakultas Kedokteran Universitas AirlanggaSurabaya, Indonesia, ${ }^{4}$ Departemen Obstetri dan Ginekologi \\ Fakultas Kedokteran Universitas Airlangga Surabaya, Indonesia
}

\begin{abstract}
Abstrak
Sindrom ovari polikistik (SOPK) meningkatkan risiko hiperplasia dan keganasan endometrium. Faktor yang memicu kejadian tersebut adalah hiperandrogen, anovulasi kronik, dan hiperinsulinemia. Terapi oksigen hiperbarik (TOHB) diketahui memberikan manfaat positif bagi sensitivitas insulin. Berdasar atas hal tersebut maka ingin diketahui pengaruh terapi oksigen hiperbarik terhadap endometrium pada tikus model SOPK resistensi insulin. Untuk mengetahui hal tersebut maka dilakukan penelitian dengan desain post-test only control group menggunakan 28 tikus betina (Rattus norvegicus strain Wistar) yang kemudian dibagi menjadi empat kelompok: Kelompok normal, SOPK, TOHB 5 sesi dengan SOPK dan TOHB 10 sesi dengan SOPK. Model tikus SOPK diperoleh dengan menyuntikkan testosteron propionat $10 \mathrm{mg} / 100$ gram bobot/ kali selama 28 hari berturutturut. Pada tikus normal diberikan suntikan propilen glikol sebanyak $1 \mathrm{~mL}$ selama 28 hari. Dilakukan pengukuran ketebalan endometrium secara histopatologik. Penelitian dilakukan di Fakultas Kedokteran Universitas Airlangga, Fakultas Kedokteran Hewan Universitas Airlangga, dan LAKESLA TNI AL Drs. Med. R. Riyadi S, Phys pada periode Juni-September 2016. Didapatkan ketebalan endometrium pada kelompok normal (mean \pm SD) $(\mu \mathrm{m})$ ) $1.109,98$ \pm 53,96; kelompok SOPK 35.651,47 \pm 400,54; kelompok TOHB 5 sesi dengan SOPK 2.266,13 \pm 2 62,08; dan kelompok TOHB 10 sesi dengan SOPK 2.144,83 \pm 305,83. Kelompok SOPK memiliki endometrium lebih tebal dibanding dengan kelompok normal. Tidak terdapat perbedaan ketebalan endometrium pascapemberian TOHB 5 sesi maupun 10 sesi.
\end{abstract}

Kata kunci: Hiperplasia endometrium, sindrom ovari polikistik, terapi oksigen hiperbarik

\section{Hyperbaric Oxygen Therapy Does Not Improve the Endometrial Thickness in PCOS Rat with Insulin Resistance Model}

\begin{abstract}
Polycystic ovary syndrome (PCOS) increases the risk of endometrial hyperplasia and malignancy. Chronic anovulation, hyperandrogen, and hyperinsulinemia are known as the pathogenesis of endometrial hyperplasia and malignancy in PCOS women. Hyperbaric oxygen therapy (HBOT) has positive effects to improve peripheral insulin sensitivity. This study aimed to understand the effect of HBOT on endometrial thickness in PCOS rat with insulin resistance model. A laboratory experimental study was conducted involving twenty-eight healthy female rats divided into 4 groups: normal group, PCOS group, 5 session HBOT PCOS group, and 10 Session HBOT PCOS group. To induce a PCOS rat model with insulin resistance, testosterone propionate $(10 \mathrm{mg} / 100$-gram body weight) was administered for 28 days. Normal group was administered with $1 \mathrm{~mL}$ propylene glycol. Histopathological evaluation of endometrium of all groups was performed. This study was conducted in June-September 2016 in the School of Medicine Airlangga University, School of Veterinary Medicine Airlangga University, and LAKESLA TNI AL Drs. Med. R. Riyadi S, Phys. The endometrial thickness (mean \pm SD $(\mu \mathrm{m})$ ) of the normal, PCOS p, 5-session HBOT PCOS, and 10-session HBOT PCOS were 1,109.98 \pm 53.96, 35,651.47 $\pm 400.54,2,266.13 \pm 262.08$, and 2,144.83 \pm 305.83 , respectively. The endometrium of PCOS group was thicker than that of the normal group. Five and ten sessions do not decrease the endometrial thickness when compared to PCOS group.
\end{abstract}

Key words: Endometrial hyperplasia, hyperbaric oxygen therapy, polycystic ovary syndrome

Korespondensi: Lunardhi Susanto, dr., M.Kes, Sp.And, Bagian Biologi Seluler, Fakultas Kedokteran Universitas Hang Tuah Surabaya, Komplek Barat RSAL Dr. Ramelan, Jalan Gadung No. 1, Jagir, Surabaya, Jawa Timur, E-mail: lunardhisusanto@gmail.com 


\section{Pendahuluan}

Sindrom ovari polikistik atau SOPK merupakan kelainan endokrinologik tersering pada wanita premenopause dengan angka kejadian berkisar 6-25 \%. ${ }^{1}$ Berdasar atas kriteria Rotterdam 2003, diagnosis SOPK dapat dibuat apabila dua dari tiga kondisi berikut terpenuhi (hiperandrogen, anovulasi, dan polikistik ovari). ${ }^{1}$ Selain itu 44$70 \%$ penderita SOPK disertai resistensi insulin. ${ }^{1,2}$

Endometrium penderita SOPK berada dalam pengaruh hiperandrogen, "unopposed estrogen" karena anovulasi kronik dan hiperinsulinemia. Ketiga hal tersebut menyebabkan endometrium mengalami pertumbuhan yang berlebih, pola perdarahan abnormal, dan peningkatan risiko hiperplasia endometrium serta keganasan pada endometrium di kemudian hari (odds ratio 5,3 ). ${ }^{2}$

Terapi oksigen hiperbarik atau TOHB didefinisikan sebagai suatu metode pengobatan dengan jalan memberikan oksigen murni (100\%) pada tekanan diatas permukaan laut (1 atmosfer absolut). ${ }^{3}$ Pemberian TOHB telah dilakukan pada banyak kondisi baik pada kasus yang terkait infertiltas pria maupun wanita. Pemberian TOHB diketahui memperbaiki motilitas spermatozoa, meningkatkan nilai anti mullerian hormone $(\mathrm{AMH})$ dan jumlah folikel antral pada wanita dengan cadangan ovarium yang rendah. ${ }^{4,5}$ Selain itu, pemberian TOHB juga dapat memperbaiki resistensi insulin. ${ }^{6}$ Pada penelitian ini ingin dibuktikan pengaruh pemberian TOHB terhadap perbaikan ketebalan endometrium pada tikus model SOPK dengan resistensi insulin.

\section{Metode}

Desain penelitian yang dipergunakan pada penelitian ini adalah post-test only control group. Penelitian dilakukan di Fakultas Kedokteran Universitas Airlangga, Fakultas Kedokteran Hewan Universitas Airlangga dan LAKESLA TNI AL Drs. Med. R. Riyadi S, Phys. Penelitian dilakukan pada periode Juni-September 2016. dan telah mendapatkan sertifikat laik etik dari Komisi Etik Penelitian Universitas Hang Tuah Surabaya (No.07/HC/EC/KEPUHT/2016). Sebanyak dua puluh delapan tikus betina (Rattus norvegicus strain Wistar) yang diperoleh dari Pusat Vetenaria Farma (PUSVETMA) di Surabaya dipergunakan sebagai hewan coba dalam penelitian ini. Kriteria inklusi yang digunakan, yaitu sehat, mempunyai bobot 250 sampai 300 gram, berusia 3 sampai 4 bulan dan tidak pernah dipergunakan sebagai hewan coba pada penelitian lain. Dilakukan adaptasi hewan coba selama 7 hari sebelum penelitian ini dilakukan. Seluruh hewan coba diletakkan dalam kandang yang berbentuk sama dan pakan yang sama. Air untuk minum diberikan ad libitum. Untuk menjamin bahwa hewan coba tersebut memiliki siklus ovulasi yang normal maka dilakukan $s w a b$ vagina. Bagi hewan coba yang tidak berada dalam fase estrus dikeluarkan dari penelitian ini. Hewan coba tersebut kemudian dibagi menjadi empat kelompok (7 ekor masing-masing) secara acak. Kelompok I (normal), kelompok II (SOPK), kelompok III (SOPK dengan TOHB 5 sesi), dan kelompok IV (SOPK dengan TOHB 10 sesi).

Model SOPK diperoleh dari pemberian testosteron propionat (testohormon $\AA$, PT Wonderindo Pratama) secara injeksi dengan dosis $10 \mathrm{mg} / 100$ gram bobot per kali selama 28 hari, sedangkan pada kelompok normal diberikan injeksi propilen glikol sebanyak $1 \mathrm{~mL}$. Pada 1 hari pascasuntikan terakhir dilakukan $s w a b$ vagina ulang pada kelompok yang telah mendapatkan injeksi testosteron propionat. Apabila hewan coba tersebut tidak berada dalam fase metestrus atau diestrus (menunjukkan anovulasi) maka hewan coba dikeluarkan dari penelitian ini. Fase metestrus atau diestrus menunjukkan keberhasilan pembuatan model SOPK dengan resistensi insulin (dua dari kriteria Rotterdam terpenuhi, yaitu hiperandrogen dan anovulasi). Selain itu, untuk lebih meyakinkan keberhasilan model SOPK tersebut dilakukan pengambilan jaringan ovarium untuk menilai polikistik ovari. Model hewan coba yang tidak dijumpai gambaran polikistik ovari dikeluarkan dari penelitian ini.

Terapi oksigen hiperbarik diberikan dengan menggunakan "animal chamber". Hewan coba pada kelompok I dan II diberikan tekanan 1 ATA dan diberikan udara selama 10 sesi berturutturut. Kelompok III diberikan tekanan 2.4 ATA 3 kali 30 menit selama 5 hari berturut-turut (sesi) dan kelompok IV diberikan tekanan 2.4 ATA 3 kali 30 menit selama 10 hari berturut-turut (sesi). Dilakukan puasa selama 8 jam pascapemberian perlakuan sesi terakhir dan kemudian dilakukan terminasi hewan coba untuk diambil jaringan endometriumnya.

Jaringan endometrium dan ovarium yang diperoleh dilakukanfiksasi dengan bufer formalin $4 \%$ selama 24 jam, kemudian dikeringkan dan dimasukkan dalam parafin untuk kemudian dipotong dengen ketebalan 2 sampai $3 \mu \mathrm{m}$ dan difiksasi pada gelas objek. Slide yang telah siap dilakukan pengecatan mempergunakan hematoksilin-eosin (HE). Pengukuran ketebalan 
Tabel 1 Ketebalan Endometrium pada Keempat Kelompok

\begin{tabular}{|c|c|c|c|c|}
\hline Sampel & $\begin{array}{l}\text { Kelompok I } \\
\text { (Normal) }\end{array}$ & $\begin{array}{l}\text { Kelompok II } \\
\text { (SOPK) }\end{array}$ & $\begin{array}{c}\text { Kelompok III } \\
\text { (TOHB } 5 \text { Sesi dan } \\
\text { SOPK) } \\
\end{array}$ & $\begin{array}{c}\text { Kelompok IV } \\
\text { (TOHB } 10 \text { Sesi dan } \\
\text { SOPK) }\end{array}$ \\
\hline 1 & $1.180,20$ & $4.212,61$ & $2.118,66$ & $1.662,60$ \\
\hline 2 & $1.023,15$ & $3.680,77$ & $2.523,43$ & $1.804,76$ \\
\hline 3 & $1.125,29$ & $4.129,07$ & $2.714,86$ & $2.543,56$ \\
\hline 4 & $1.089,02$ & $3.201,77$ & $2.016,67$ & $2.199,56$ \\
\hline 5 & $1.078,77$ & $3.204,67$ & $2.190,45$ & $2.304,56$ \\
\hline 6 & $1.105,67$ & $3.532,45$ & $2.267,02$ & $2.287,02$ \\
\hline 7 & $1.167,77$ & $3.598,95$ & $2.031,87$ & $2.212,76$ \\
\hline $\begin{array}{c}\text { Mean } \\
(\mu \mathrm{m}) \pm S D\end{array}$ & $1.109,98 \pm 53,96$ & $35.651,47 \pm 400,54$ & $2.266,13 \pm 262.08$ & $2.144,83 \pm 305,83$ \\
\hline
\end{tabular}

endometrium dilakukan oleh peneliti kedua.

Data yang diperoleh kemudian dilakukan tabulasi untuk memperlihatkan gambaran deskriptif. Analisis komparasi data dilakukan menggunakan uji ANOVA satu arah dan juga dilanjutkan dengan uji LSD apabila data berdistribusi normal dan homogen, apabila data tidak berdistribusi normal dan atau tidak homogen maka akan dilakukan uji KruskalWallis dan dilanjutkan dengan Uji Mann-Whitney with Bonferroni Adjustment. Nilai $\mathrm{p}<0.05$ dianggap bermakna pada penelitian ini. SPSS 21 dipergunakan untuk melakukan analisis data.

\section{Hasil}

Didapatkan ketebalan endometrium kelompok normal (mean \pm SD) $(\mu \mathrm{m})$ ) 1.109,98 \pm 53.96 ; kelompok SOPK 35.651,47 \pm 400.54 ; kelompok TOHB 5 sesi dengan SOPK 2.266,13 $\pm 262,08$; dan kelompok TOHB 10 sesi dengan SOPK $2.144,83 \pm 305,83$ (Tabel 1). Sindrom ovari polikistik (SOPK) meningkatkan ketebalan endometrium secara bermakna bila dibanding dengan kelompok normal. Tidak terdapat perbedaan bermakna ketebalan endometrium pascapemberian TOHB baik 5 atau 10 hari berturut-turut dibanding dengan kelompok SOPK.

\section{Pembahasan}

Endometrium pada penderita SOPK dibentuk oleh kondisi hiperandrogen, hiperinsulinemia, dan "unopposed estrogen". Tidak terdapat progesteron pada endometrium mengakibatkan endometrium gagal untuk bertransformasi menjadi endometrium fase sekresi sehingga endometrium pada SOPK adalah endometrium yang mendapatkan pajanan estrogen terus menerus. Selain itu respons endometrium terhadap progesteron tersebut menurun pada penderita SOPK. Kondisi hiperandrogen dan hiperinsulinemia juga memicu proliferasi sel

Tabel 2 Perbandingan Ketebalan Endometrium pada Tiap-tiap Kelompok

\begin{tabular}{lcc}
\hline & $\mathbf{p}$ & Keterangan \\
\hline Kelompok I/Kelompok II & 0,000 & $\mathrm{~B}$ \\
Kelompok I/Kelompok III & 0,097 & TB \\
Kelompok I/Kelompok IV & 0,106 & TB \\
Kelompok II/ Kelompok III & 0,106 & TB \\
Kelompok II/ Kelompok IV & 0,097 & TB \\
Kelompok III/ Kelompok IV & 1,00 & TB \\
\hline
\end{tabular}

Keterangan: p: Uji Mann-Whitney with Bonferroni Adjustment; B: bermakna; TB: tidak bermakna 


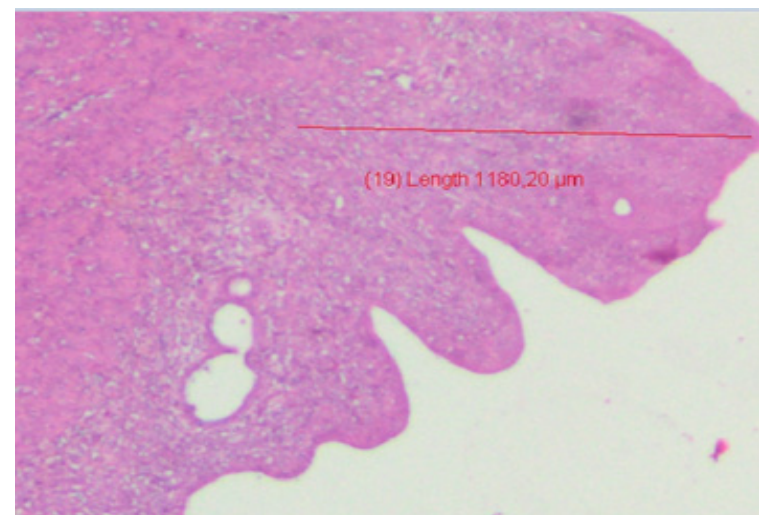

Gambar 1 Pengukuran Ketebalan Endometrium Kelompok 1 (normal) Menggunakan Perbesaran 400 kali dan Diperoleh Hasil 1.180,20 $\mu \mathrm{m}$

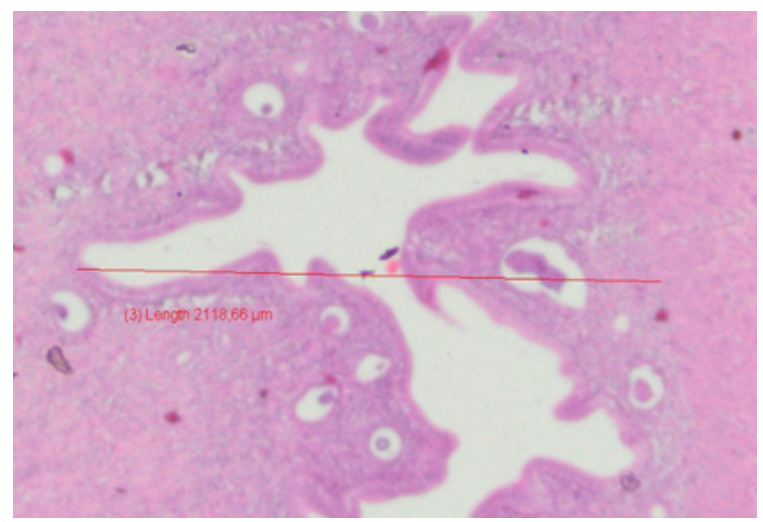

Gambar 3 Pengukuran Ketebalan Endometrium Kelompok III (TOHB 5 Sesi dan SOPK) Menggunakan Perbesaran 400 kali dan Diperoleh Hasil 2.118,66 $\mu \mathrm{m}$

secara berlebihan. ${ }^{7}$

Pada penelitian yang telah dilakukan tampak bahwa pajanan testosteron yang telah dilakukan untuk membuat model SOPK juga meningkatkan ketebalan endometrium secara bermakna bila dibanding dengan kelompok kontrol. Pemberian TOHB 2.4 ATA 3 kali 30 menit dengan air breaks selama 5 menit, 5 dan 10 sesi menurunkan ketebalan endometrium bila dibanding dengan kelompok SOPK namun penurunan ini tidak bermakna secara statistik.

Pemberian TOHB diharapkan memperbaiki kondisi hiperinsulinemia, anovulasi sehingga terjadi perbaikan pada morfologi endometrium, namun tampaknya hal tersebut tidak terjadi. Pemberian TOHB 2.4 ATA selama 90 menit, dua kali dalam sehari selama 5 sesi pada tikus model SOPK dengan resistensi insulin

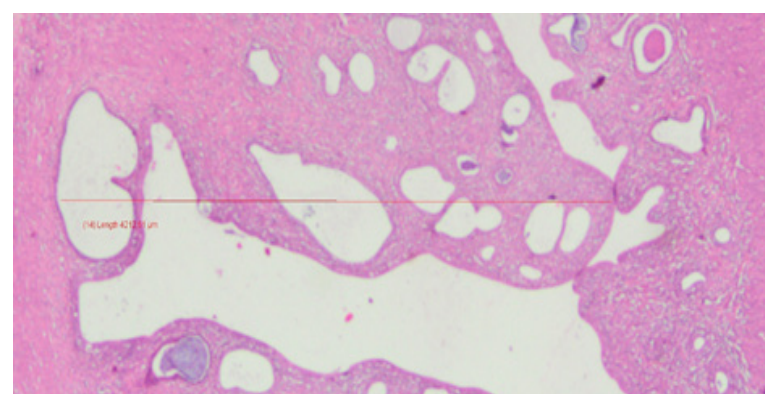

Gambar 2 Pengukuran Ketebalan Endometrium Kelompok II (SOPK) Menggunakan Perbesarran 400 kali dan Diperoleh Hasil 4.212,61 $\mu \mathrm{m}$

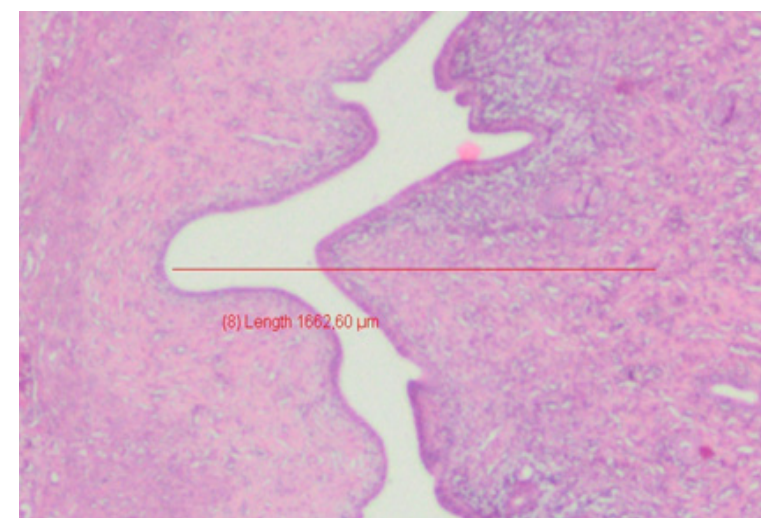

Gambar 4 Pengukuran Ketebalan Endometrium Kelompok III (TOHB 5 Sesi dan SOPK) Menggunakan Perbesaran 400 kali dan Diperoleh Hasil 1.162,60 $\mu \mathrm{m}$

dengan perlakuan yang sama pada penelitian ini menurunkan ekspresi GLUT-4 pada otot skelet secara bermakna. ${ }^{8}$ Penurunan ekspresi GLUT-4 tersebut dapat diartikan bahwa TOHB memperburuk resistensi insulin yang terjadi pada tikus model SOPK. Perbaikan kondisi hiperandrogen dapat pula ditunjukkan dengan ada perbaikan folikulogenesis, namun pada penelitian tersebut pemberian TOHB juga tidak memperbaiki folikulogenesis. ${ }^{8}$ Penting juga untuk difahami bahwa manfaat TOHB diperoleh melalui hiperoksia jaringan. Adanya hiperoksia jaringan pada satu sisi akan memberikan dampak yang positf namun pada sisi yang lain, kondisi hiperoksia jaringan juga akan mengakibatkan terjadi stres oksidatif. ${ }^{9}$ Pada dasarnya penderita SOPK tersebut telah mengalami stres oksidatif. ${ }^{1}$ Terjadinya stres oksidatif pada pemberian TOHB 
dengan dosis yang lebih panjang diketahui meningkatkan jumlah folikel atresia. ${ }^{10}$

Berdasar atas hal tersebut maka dapat disimpulkan bahwa TOHB adalah pisau bermata dua, di satu sisi dapat memberikan manfaat positif, namun di sisi lainnya dapat merugikan sehingga penentuan dosis (besar tekanan, lama pemberian) sangat menentukan manfaat yang akan diperoleh. Dosis yang sesuai pada satu kondisi belum tentu dapat diaplikasikan pada kondisi yang lainnya. Diperlukan penelitianpenelitian lebih lanjut untuk dapat mengetahui manfaat dan dampak dari TOHB.

\section{Daftar Pustaka}

1. Macut D, Macut J, Bjekić-Macut J, Rahelić D, Doknić M. Insulin and the polycystic ovary syndrome. Diabetes Res Clin Pract. 2017;130:163-70.

2. Nandi A, Chen Z, Patel R, Poretsky L. Polycystic ovary syndrome. Endocrinol Metab Clin N Am. 2014;43(1):123-47.

3. Mehta V, De A, Balachandran C. Hyperbaric oxygen therapy. JPAD. 2009;19:164-7.

4. Mitrovic A, Brkic P Jovanovic T. The effects of hyperbaric oxygen treatment on vigility of spermatozoid: preliminary report. Acta Physiol Hung. 2011;98(1):85-90.

5. Pineda JFG, Ortiz CGSL, Mougel GDJS, Lopez CREC, Slcocer HM, Velasco ST. Improvement in serum anti-mullerian hormone levels in infertile patients after hyperbaric oxygen (preliminary results). JBRA Assist Reprod. 2015;19(2):87-90.

6. Wilkinson D, Chapman M, Heilbronn LK. Hyperbaric oxygen therapy improves peripheral insulin sensitivity in humans. Diabet Med. 2012;29(8):986-9.

7. Dumesic DA, Lobo RA. Cancer risk and PCOS. Steroid. 2013;78(8):782-85.

8. Veterini V, Santoso B, Widjiati. Oxygen hyperbaric exposure induces GLUT4 expression reduction and no folliculogenesis alterations in rat PCOS with insulin resistance model. MOG. 2015; 23(3):112-7.

9. Thom SR. Oxidative stress is fundamental to hyperbaric oxygen therapy. J Appl Physiol. 2008;106:988-95.

10. Atis A, Aydin Y, Ciftci F, Sakiz D, Arsian A, Toklu AS, dkk. Hyperbaric oxygen increase atresia in normal \& steroid induce PCO rat ovaries. Reprod Biol Endocrinol. 2012;10:11. 